\title{
OPEN Complexed trace mineral supplementation alters antioxidant activities and expression in response to trailer stress in yearling horses in training
}

\author{
Christine M. Latham ${ }^{1}$, Emily C. Dickson ${ }^{1}$, Randi N. Owen ${ }^{1}$, Connie K. Larson ${ }^{2}$ \&
} Sarah H. White-Springer ${ }^{1 \times}$

To test the hypothesis that complexed trace mineral supplementation would increase antioxidant capacity and decrease muscle oxidative stress and damage in young horses entering an exercise training program, Quarter Horses (mean $\pm S D ; 9.7 \pm 0.7 \mathrm{mo}$ ) balanced by age, sex, and BW were assigned to receive complexed (CTM; $n=8$ ) or inorganic (INORG; $n=8$ ) trace minerals at -12 week relative to this study. Blood and muscle samples were collected before (week 0 ) and after 12 week of light exercise training surrounding a 1.5-h trailer stressor. Muscle glutathione peroxidase (GPx) activity was higher for CTM than INORG horses $(P \leq 0.0003)$ throughout the study. Following both trailer stressors, serum creatine kinase increased $(P<0.0001)$ and remained elevated through $24 \mathrm{~h}$ posttrailering $(P<0.0001)$. At week 0 , muscle malondialdehyde, expression of superoxide dismutase 2 , and whole blood GPx activity increased $(P \leq 0.003)$ following trailering but trailering did not affect these measures at week 12. Young horses supplemented with CTM had higher muscle GPx activity than horses receiving INORG, but CTM did not affect damage markers following a stressor. Dietary CTM may be useful for improving antioxidant capacity during exercise training in young equine athletes.

Young equine athletes experience several stressors as they enter training and competition. Acute exercise bouts and trailer transportation between competitions or training facilities may cause an increase in mitochondrial production of reactive oxygen species (ROS), which can be deleterious to skeletal muscle health if not properly sequestered by antioxidant enzymes. Dietary complexed trace mineral supplementation has been shown to reduce oxidative stress in food animal models ${ }^{1-3}$. Dietary proteinate complexed-Zn supplementation increased glutathione peroxidase (GPx) and superoxide dismutase (SOD) activities in the spleen of barrows ${ }^{4}$. Additionally, biocomplexed minerals $\mathrm{Fe}, \mathrm{Mn}, \mathrm{Zn}$, and $\mathrm{Cu}$ enhanced SOD and GPx activities in the liver of grower-finisher pigs ${ }^{5}$ and decreased plasma malondialdehyde (MDA), a measure of oxidative stress, in broilers ${ }^{1}$.

In horses, research on the effects of dietary organic trace mineral supplementation is limited. One study in horses demonstrated $\mathrm{Cu}$-Lys may be better absorbed than $\mathrm{CuSO}_{4}{ }^{6}$. However, in the same group of horses, $\mathrm{Cu}-\mathrm{Lys}$ and $\mathrm{Zn}$-Met supplementation did not seem superior to $\mathrm{CuSO}_{4}$ and $\mathrm{ZnSO}_{4}$ in improving erythrocyte SOD activity during a 1-h standardized exercise test and immediately after recovery in horses ${ }^{7}$. It should be noted that exercise itself did not induce a change in SOD activity in that study, suggesting the exercise did not significantly increase systemic oxidative stress ${ }^{7}$. Additionally, supplemented mineral intakes of $\mathrm{Cu}$-Lys and $\mathrm{Zn}$-Met were higher than $\mathrm{CuSO}_{4}$ and $\mathrm{ZnSO}_{4}$, making interpretation of the results difficult.

In the present study, horses were maintained on a diet containing either complexed or inorganic trace minerals for 12 weeks, and then light exercise training was initiated. Horses were maintained on their respective diets and underwent the light exercise training program with blood and muscle samples from the triceps brachii (TB) and gluteus medius (GM) collected surrounding trailer stressors before (week 0) and after 12 week of exercise training. Our objective was to test the hypothesis that complexed trace mineral supplementation would increase systemic and muscle antioxidant gene expression and enzyme activities, and decrease oxidative stress and muscle

\footnotetext{
${ }^{1}$ Texas A\&M Department of Animal Science, Texas A\&M AgriLife Research, College Station, TX 77843, USA. ${ }^{2}$ Zinpro Corporation, Eden Prairie, MN 55344, USA. ${ }^{\square}$ email: shwhite@tamu.edu
} 


\begin{tabular}{|c|c|c|c|c|c|c|c|c|c|}
\hline \multirow[b]{2}{*}{ Variable } & \multirow[b]{2}{*}{ Muscle } & \multirow[b]{2}{*}{ Diet } & \multicolumn{2}{|c|}{ Week } & \multirow[b]{2}{*}{ SEM } & \multicolumn{4}{|l|}{$P$ value } \\
\hline & & & 0 & 12 & & Muscle & Diet & Time & Muscle $\times$ Diet $\times$ Time \\
\hline \multicolumn{10}{|l|}{ Muscle } \\
\hline \multirow{4}{*}{ MDA concentration ( $\mathrm{pmol} / \mathrm{mg}$ protein) } & \multirow{2}{*}{ GM } & CTM & $56^{\#}$ & $50^{\#}$ & 7 & 0.0002 & 0.486 & 0.066 & 0.394 \\
\hline & & INORG & $58^{\#}$ & $40^{* *}$ & & & & & \\
\hline & \multirow{2}{*}{$\mathrm{TB}$} & CTM & 60 & 69 & & & & & \\
\hline & & INORG & 85 & $65^{*}$ & & & & & \\
\hline Serum & & & & & & & Diet & Time & Diet $\times$ Time \\
\hline \multirow{2}{*}{ CK activity (units/L) } & - & CTM & 83 & $73^{*}$ & 5 & & 0.095 & 0.012 & 0.438 \\
\hline & & INORG & 77 & $59^{*}$ & & & & & \\
\hline
\end{tabular}

Table 1. Pre-trailer muscle malondialdehyde (MDA) concentrations in the gluteus medius (GM) and triceps brachii (TB) and serum creatine kinase (CK) activity at 0 and 12 weeks of submaximal exercise training in yearling horses supplemented with either complexed trace minerals (CTM; $n=8)$ or inorganic trace minerals (INORG; $\mathrm{n}=8)$. ${ }^{*}$ Within a row, mean differs from week $0(P \leq 0.05) .{ }^{*}$ Within a column, GM differs from TB $(P \leq 0.05)$.

damage in response to trailering stress in yearling Quarter Horses enrolled in a submaximal exercise training program.

\section{Results}

Responses to time, diet and exercise training. Growth. Body weight, heart girth, body length, wither height and hip height increased by week 12 (Supplemental Table S1 $P<0.0001$ ) as expected with normal growth. With exercise training, body condition score decreased from 6.1 at week 0 to 5.5 at week 12 (Supplemental Table S1; $P<0.0001$ ). Body length (colt $149 \pm 1 \mathrm{~cm}$; filly $145 \pm 1 \mathrm{~cm}$ ) and body weight (colt $321 \pm 6 \mathrm{~kg}$; filly $303 \pm 7 \mathrm{~kg}$ ) tended to be greater for colts than fillies $(P \leq 0.07)$ but sex did not affect any other growth measurements $(P>0.10)$. No growth measurements were affected by diet or the diet $\times$ time interaction.

Oxidative stress and muscle damage. A diet $\times$ time interaction $(P=0.04)$ revealed that muscle MDA concentrations were greater for INORG than CTM horses at week $0(P=0.05)$. However, MDA decreased from week 0 to 12 in INORG horses $(P=0.006$; Table 1$)$ but remained unchanged in CTM horses, resulting in similar MDA levels between dietary treatment groups at week 12. Concentrations of MDA were greater in the TB than the GM for both dietary treatment groups throughout the study $(P=0.0002)$.

Resting serum CK activity tended to be greater for CTM than INORG horses $(P=0.09)$ throughout the current study (Table 1). Pre-trailer serum CK activity decreased from week 0 to $12(P=0.01$; Table 1$)$ for both treatment groups.

Antioxidant activities. Overall, GPx activity was greater for CTM than INORG horses in both muscle groups $(P=0.002)$, and was greater in the TB than the GM $(P=0.007)$ for both treatments, but was not affected by time (Table 2). A main effect of time $(P=0.05)$ showed that muscle SOD activity increased from week 0 to 12 . However, a trend for an effect of the diet $\times$ time interaction on resting muscle SOD activity $(P=0.08)$ revealed that SOD activity increased from week 0 to 12 in CTM $(P=0.007)$ but did not change in INORG horses. Neither resting whole blood GPx nor SOD activities were affected by time, diet, or their interaction (Table 2).

Muscle antioxidant gene expression. Pre-trailer SOD1 expression was greater in the GM than the TB $(P=0.04)$ but was not affected by diet, time or any interactions (Table 3). A time $\times$ muscle group interaction $(P=0.0004)$ showed that pre-trailer SOD2 expression was greater in the TB than the GM at week $0(P<0.0001)$ but increased in the GM by week $12(P=0.003$; Table 3$)$. A diet $\times$ muscle group interaction $(P=0.05)$ indicated that SOD2 expression was greater for CTM than INORG horses in the GM $(P=0.02)$, and was greater in the TB than the GM for INORG horses $(P=0.0009)$ but was not different between muscle groups in CTM horses.

Responses to trailer stressors. Oxidative stress and muscle damage. At week 0, pre-trailer MDA of INORG horses was greater in the TB than the GM $(P=0.02)$. Malondialdehyde in the TB of INORG horses then tended to decrease at $1 \mathrm{~h}$ post-trailer $(P=0.10)$ and increased at $24 \mathrm{~h}$ post-trailer $(P=0.03$; Fig. 1a). There was no change in GM MDA of INORG horses, which resulted in greater MDA in the TB than GM $24 \mathrm{~h}$ after trailering in INORG horses $(P=0.0001)$. In CTM horses, TB MDA concentration was not affected by trailering, but GM MDA increased $24 \mathrm{~h}$ after trailering $(P=0.001$; Fig. 1a). Due to the different changes in muscle groups between CTM and INORG horses, MDA was greater in the GM of CTM compared to INORG horses $(P=0.003)$ and tended to be greater in the TB of INORG compared to CTM horses $(P=0.10) 24 \mathrm{~h}$ post-trailering. At week 12 , MDA concentration was greater in the TB than the GM $(P<0.0001)$. A trend for a time $\times$ muscle group interaction $(P=0.06)$ indicated that MDA concentration increased in the GM at $1 \mathrm{~h}$ post-trailer $(P=0.002)$ and decreased from 1 to $24 \mathrm{~h}$ post-trailer $(P=0.05$; Fig. $1 \mathrm{~b})$ but MDA was unaffected by trailering in the TB. Diet did not influence MDA responses to trailering at week 12 . 


\begin{tabular}{|c|c|c|c|c|c|c|c|c|c|}
\hline \multirow[b]{2}{*}{ Variable } & \multirow[b]{2}{*}{ Muscle } & \multirow[b]{2}{*}{ Diet } & \multicolumn{2}{|l|}{ Week } & \multirow[b]{2}{*}{ SEM } & \multicolumn{4}{|l|}{$P$ value } \\
\hline & & & 0 & 12 & & Muscle & Diet & Time & Muscle $\times$ Diet $\times$ time \\
\hline \multicolumn{10}{|l|}{ Muscle } \\
\hline \multirow{4}{*}{$\begin{array}{l}\text { GPx activity }\left(\mathrm{nmol} \bullet \mathrm{min}^{-1} \bullet \mathrm{mg}\right. \\
\text { protein }\end{array}$} & \multirow{2}{*}{ GM } & CTM & $12.72^{\mathrm{at}}$ & $11.06^{\mathrm{a} \#}$ & 2.04 & 0.007 & 0.002 & 0.415 & 0.963 \\
\hline & & INORG & $9.19^{\mathrm{bt}}$ & $5.73^{\mathrm{bt}}$ & & & & & \\
\hline & \multirow{2}{*}{$\mathrm{TB}$} & CTM & $17.65^{\mathrm{a}}$ & $17.91^{\mathrm{a}}$ & & & & & \\
\hline & & INORG & $8.89^{\mathrm{b}}$ & $10.31^{\mathrm{b}}$ & & & & & \\
\hline \multirow{4}{*}{$\begin{array}{l}\text { SOD activity }\left(\mathrm{nmol} \cdot \mathrm{min}^{-1} \cdot \mathrm{mg}\right. \\
\left.\text { protein }^{-1}\right)\end{array}$} & \multirow{2}{*}{ GM } & CTM & $2.03^{\#}$ & $3.00^{* \#}$ & 0.44 & 0.001 & 0.627 & 0.043 & 0.559 \\
\hline & & INORG & $2.73^{\#}$ & $2.50^{\sharp}$ & & & & & \\
\hline & \multirow{2}{*}{$\mathrm{TB}$} & CTM & 2.81 & $3.78^{*}$ & & & & & \\
\hline & & INORG & 3.36 & 3.74 & & & & & \\
\hline Whole blood & & & & & & & Diet & Time & Diet $\times$ Time \\
\hline \multirow{2}{*}{$\begin{array}{l}\text { GPx activity }\left(\mathrm{nmol} \cdot \mathrm{min}^{-1} \cdot \mathrm{mg}\right. \\
\text { protein }\end{array}$} & - & CTM & 20.57 & 22.46 & 3.92 & & 0.190 & 0.698 & 0.852 \\
\hline & - & INORG & 24.77 & 25.43 & & & & & \\
\hline \multirow{2}{*}{$\begin{array}{l}\text { SOD activity }\left(\mathrm{nmol} \cdot \mathrm{min}^{-1} \cdot \mathrm{mg}\right. \\
\left.\text { protein }^{-1}\right)\end{array}$} & - & CTM & 0.21 & 0.23 & 0.03 & & 0.284 & 0.804 & 0.507 \\
\hline & - & INORG & 0.18 & 0.18 & & & & & \\
\hline
\end{tabular}

Table 2. Pre-trailer muscle glutathione peroxidase (GPx) and superoxide dismutase (SOD) activities in the gluteus medius (GM) and triceps brachii (TB), and whole blood GPx and SOD activities at 0 and 12 weeks of submaximal exercise training in yearling horses supplemented with either complexed trace minerals $(\mathrm{CTM} ; \mathrm{n}=8)$ or inorganic trace minerals (INORG; $\mathrm{n}=8)$. ${ }^{\star}$ Within a row, mean differs from week $0(P \leq 0.05)$. ${ }^{\mathrm{a}, \mathrm{b}}$ Within a column, differing letters indicate CTM differs from INORG within the specified variable $(P \leq 0.05)$. \#Within a column, GM differs from TB $(P \leq 0.05)$.

\begin{tabular}{|c|c|c|c|c|c|c|c|c|c|}
\hline \multirow[b]{2}{*}{ Variable } & \multirow[b]{2}{*}{ Muscle } & \multirow[b]{2}{*}{ Diet } & \multicolumn{2}{|l|}{ Week } & \multirow[b]{2}{*}{ SEM } & \multicolumn{4}{|l|}{$P$ value } \\
\hline & & & 0 & 12 & & Muscle & Diet & Time & Muscle $\times$ Diet $\times$ Time \\
\hline \multirow{4}{*}{$S O D 1(40-\Delta \mathrm{Cq})$} & \multirow{2}{*}{$\mathrm{GM}^{\#}$} & CTM & 39.90 & 39.86 & 0.10 & 0.013 & 0.252 & 0.545 & 0.063 \\
\hline & & INORG & 39.89 & 39.97 & & & & & \\
\hline & \multirow{2}{*}{ TB } & CTM & 39.67 & 39.67 & & & & & \\
\hline & & INORG & 39.82 & 39.77 & & & & & \\
\hline \multirow{4}{*}{$S O D 2(40-\Delta \mathrm{Cq})$} & \multirow{2}{*}{ GM } & CTM & $39.46^{\mathrm{a}, \mathrm{y}}$ & $39.78^{\mathrm{b}, y \star}$ & 0.10 & 0.005 & 0.196 & 0.177 & 0.992 \\
\hline & & INORG & $39.26^{\mathrm{a}, \mathrm{x}}$ & $39.56^{\mathrm{b}, \mathrm{x} *}$ & & & & & \\
\hline & \multirow{2}{*}{$\mathrm{TB}$} & CTM & $39.74^{\text {b,y }}$ & $39.63^{\text {b,y }}$ & & & & & \\
\hline & & INORG & $39.82^{\mathrm{b}, \mathrm{y}}$ & $39.69^{\mathrm{b}, \mathrm{y}}$ & & & & & \\
\hline
\end{tabular}

Table 3. Pre-trailer muscle $\mathrm{Cu}-\mathrm{Zn}$ superoxide dismutase (SOD1) and $\mathrm{Mn}$ superoxide dismutase (SOD2) expression in the gluteus medius (GM) and triceps brachii (TB) at 0 and 12 weeks of submaximal exercise training in yearling horses supplemented with either complexed trace minerals $(C T M ; n=8)$ or inorganic trace minerals (INORG; $\mathrm{n}=8) .{ }^{*}$ Within a variable, GM differs from TB $(P \leq 0.05)$. ${ }^{*}$ Within a row, mean differs from week $0(P \leq 0.05) .{ }^{\mathrm{a}, \mathrm{b}}$ Means with different letters differ $(P \leq 0.05)$ due to muscle $\times$ time interaction $(P=0.0004)$. ${ }^{\mathrm{x}, \mathrm{y}}$ Means with different letters differ $(P \leq 0.05)$ due to muscle $\times$ diet interaction $(P=0.05)$.

Following both trailer stressors, serum CK activity increased immediately after trailering $(0 \mathrm{~h} ; P<0.0001)$ and remained elevated through 24 h post-trailer $(P<0.0001$; Fig. 2$)$ for both treatments. At week 12 but not week 0 , CK activity decreased from 6 to 24 h post-trailer $(P=0.007$; Fig. $2 b)$. Serum CK activity following trailering was unaffected by diet.

Antioxidant activities. Overall, GPx activity was greater for CTM than INORG horses in both muscle groups $(P \leq 0.0003$; Fig. 3a,b), and greater in the TB than the GM $(P \leq 0.005)$ throughout both trailer stressors. In response to trailering at week 0 , a trend for an effect of trailering $(P=0.06)$ suggested that $\mathrm{GPx}$ activity increased $24 \mathrm{~h}$ after trailering $(P=0.03$; Fig. $3 \mathrm{a})$ in both muscle groups. At week 12 , a trend for a trailering $\times$ muscle group interaction $(P=0.07)$ suggested that GPx activity increased in the GM $1 \mathrm{~h}$ after trailering $(P=0.0004)$ and remained elevated through $24 \mathrm{~h}$ post-trailer $(P=0.02)$, but did not change in response to trailering in the TB (Fig. 3b).

Muscle SOD activity tended to be greater for INORG than CTM horses throughout the week 0 trailer stressor in both muscle groups $(P=0.08$; Fig. $3 \mathrm{c})$ but was not different between dietary treatments during the week 12 trailer stressor (Fig. 3d). Activity of SOD was greater in the TB than the GM throughout both trailer stressors $(P \leq 0.0008)$ but was not affected by trailering at week 0 or 12 . 


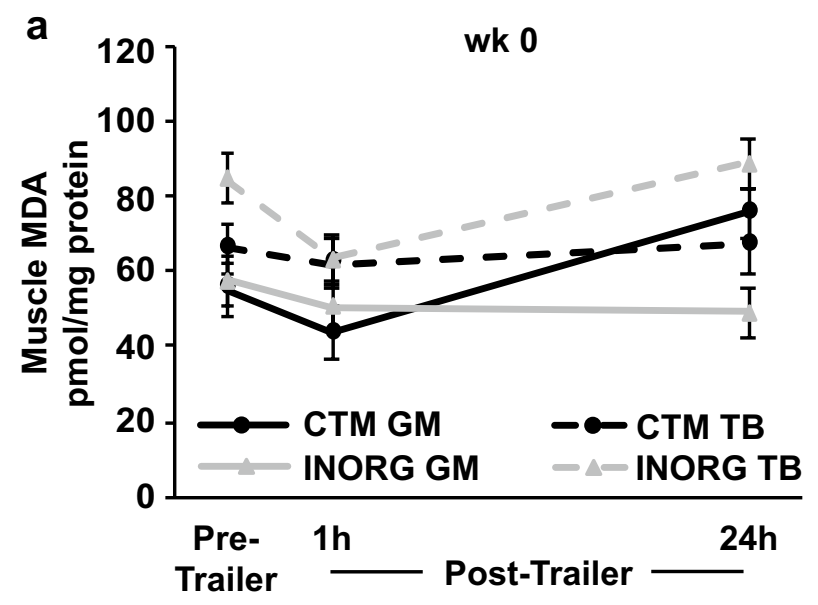

b

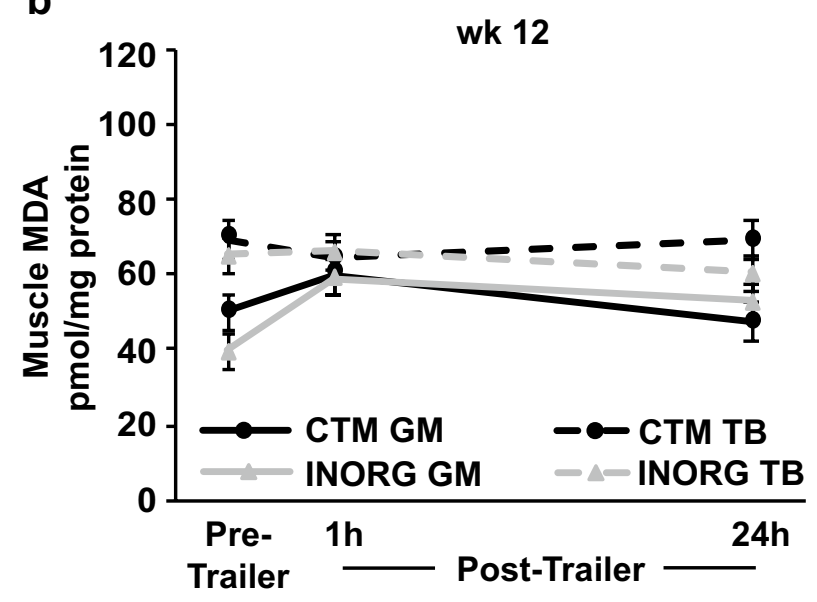

Figure 1. Muscle malondialdehyde (MDA) concentration before (Pre-Trailer), and $1(1 \mathrm{~h})$ and $24 \mathrm{~h}(24 \mathrm{~h})$ after a 1.5-h trailer stressor. Trailer stressors occurred before (week 0 ; a) and after (week 12; b) 12 weeks of submaximal exercise training in yearling horses supplemented with either complexed trace minerals (CTM; $\mathrm{n}=8$ ) or inorganic trace minerals (INORG; $\mathrm{n}=8)$. Overall effect of diet $(P=0.306 ; P=0.226)$, trailering $(P=0.011 ; P=0.172)$, muscle group $(P<0.0001 ; P<0.0001)$, diet $\times$ trailering $(P=0.258 ; P=0.596)$, diet $\times$ muscle group $(P=0.014 ; P=0.945)$, time $\times$ muscle group $(P=0.840 ; P=0.119)$ and $\operatorname{diet} \times$ time $\times$ muscle group $(P=0.071 ; P=0.450)$ for panels a and $\mathrm{b}$ respectively.

At week 0, GPx activity in whole blood tended to increase from pre-trailer to $1 \mathrm{~h}$ post-trailer $(P=0.10)$ and continued increasing to $6 \mathrm{~h}$ post-trailer $(P=0.007)$ but returned to pre-trailer levels by $24 \mathrm{~h}$ post-trailer (Supplemental Figure S1). Blood GPx activity at week 12 and blood SOD activity at week 0 and 12 were not affected by dietary treatment, trailering, or their interaction (Supplemental Figure S1).

Muscle antioxidant gene expression. At week 0, SOD1 expression was not affected by diet, trailering, or any interactions, and was not different between muscle groups (Fig. 4a). At week 12, SOD1 expression was not affected by trailering but was greater for INORG than CTM horses $(P=0.03)$ and was greater in the GM than the TB $(P=0.05$; Fig. 4 b) throughout the trailering stressor.

Expression of SOD2 increased in response to the week 0 trailer stressor at $24 \mathrm{~h}$ post-trailer in both muscle groups of all horses $(P<0.0001$; Fig. $4 \mathrm{c})$. A trend for a diet $\times$ time interaction suggested that SOD2 expression was greater for CTM than INORG horses at $24 \mathrm{~h}$ post-trailer $(P=0.008)$. During the week 12 trailer stressor, SOD2 expression decreased at $1 \mathrm{~h}$ post-trailer in the GM for CTM horses $(P=0.004$; Fig. $4 \mathrm{~d})$, and then increased from 1 to 24 h post-trailer $(P<0.0001)$ resulting in greater SOD2 expression for CTM than INORG horses in the GM at $24 \mathrm{~h}$ post-trailer $(P=0.0007)$. In the TB, INORG SOD2 expression increased $24 \mathrm{~h}$ after trailering $(P=0.02)$, but was not different from pre-trailer or CTM horses at $24 \mathrm{~h}$ post-trailer.

\section{Discussion}

The present study examined the effects of trace mineral supplementation and trailering on oxidative stress and antioxidant status in growing horses undergoing a submaximal exercise training program. Compared to supplementation with inorganic trace minerals, complexed trace minerals conferred few advantages to unstressed, exercising yearling horses regarding oxidative stress and muscle perturbation. However, CTM horses showed 

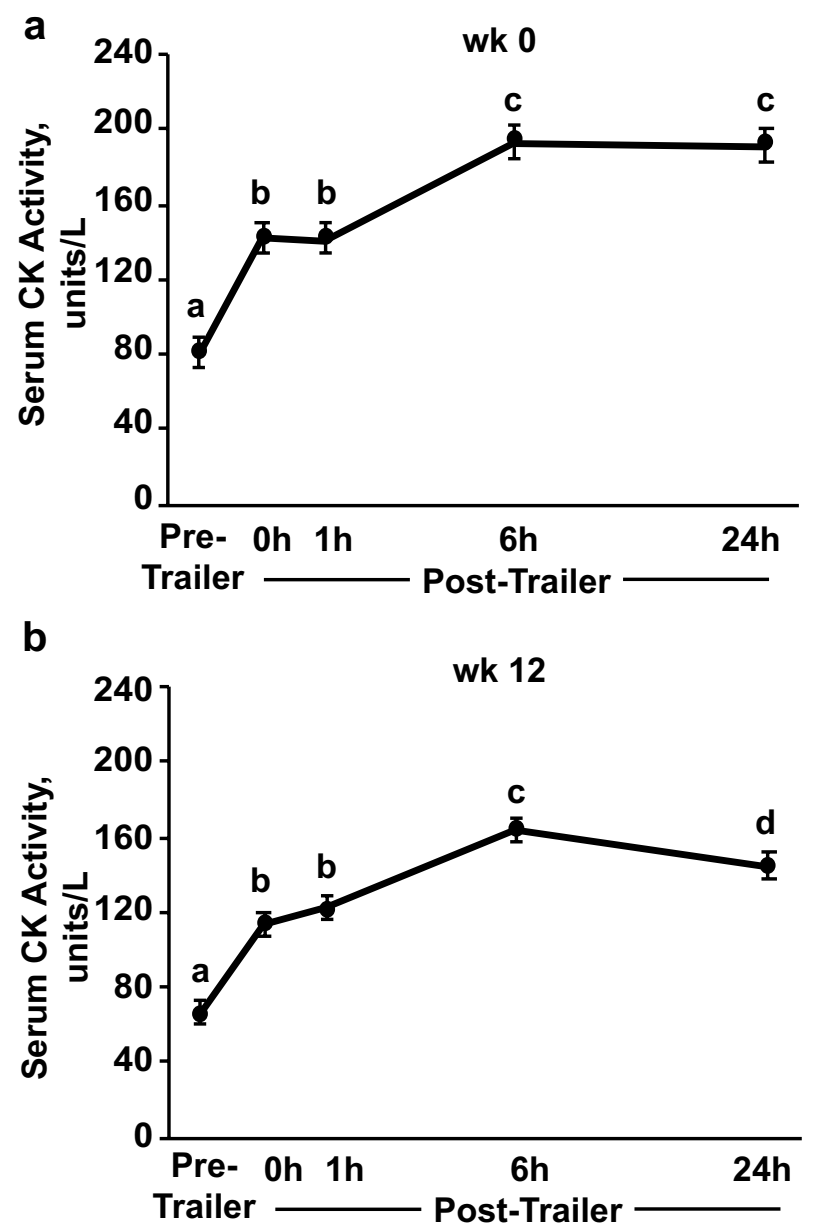

Figure 2. Serum creatine kinase (CK) activity before (Pre-Trailer), and 0, 1, 6, and $24 \mathrm{~h}$ after $(0 \mathrm{~h}, 1 \mathrm{~h}, 6 \mathrm{~h}$, and $24 \mathrm{~h}$, respectively) a 1.5-h trailer stressor. Trailer stressors occurred before (week 0; a) and after (week 12; b) 12 weeks of submaximal exercise training in yearling horses $(n=16)$. Due to lack of effect of diet, dietary treatments have been combined. Overall effect of trailering $(P<0.0001 ; P<0.0001)$ for panels $\mathbf{a}$ and $\mathbf{b}$, respectively. ${ }^{\mathrm{a}-\mathrm{d}}$ Time points lacking common letters differ $(P \leq 0.05)$.

improved muscle GPx activity both prior to and during a 1.5-h trailer stressor, as well as an increase in resting muscle SOD activity through 12 weeks of exercise training. Regardless of diet, 12 weeks of exercise training and growth resulted in a decrease in resting markers of oxidative stress (MDA) and muscle permeability (serum $\mathrm{CK}$ ) but no significant change in antioxidant status. Additionally, the 1.5-h trailer stressor utilized in this study resulted in an increase in serum CK activity, indicating its usefulness as a muscle perturbation model in young horses.

Muscle MDA concentration was used as a marker of oxidative stress in the current study. Resting MDA concentrations (pre-trailer) were higher for INORG than CTM horses at week 0, but decreased for INORG horses by week 12 . The elevated muscle MDA concentration for INORG horses at week 0 was not mirrored by an elevated resting serum CK activity, suggesting that the difference in MDA concentration was not physiologically significant enough to result in muscle perturbation at rest. Alternatively, a different marker of muscle damage may be useful in examining resting muscle health, as serum CK activity is typically used as a marker of muscle damage following an acute stressor.

Creatine kinase is an enzyme found primarily in muscle, and its activity in the serum has been shown to increase in response to strenuous exercise as a result of altered muscle cell membrane permeability ${ }^{8}$ or muscle damage ${ }^{9}$. While serum CK activity of horses in the present study remained within normal reference ranges, horses exhibited an increase in serum CK activity in response to each trailer stressor. This was expected based on previous literature ${ }^{10,11}$ and suggested that $1.5 \mathrm{~h}$ of trailering caused sufficient perturbation to muscle cells in this study. While not statistically compared, it is important to note that serum CK peaked around 200 units/L following the week 0 trailer stressor, but only increased to around 160 units/L following the week 12 trailer stressor. Combined with the decrease in serum CK activity at $24 \mathrm{~h}$ post-trailering at week 12 , and the lack of effect of trailering on muscle MDA, the data indicate that 12 weeks of exercise training and growth in yearlings mitigated transportation-induced oxidative stress and muscle perturbation. Unfortunately, one limitation of this study is the lack of a non-exercised control group. Therefore, it is not possible to distinguish the effects of exercise 


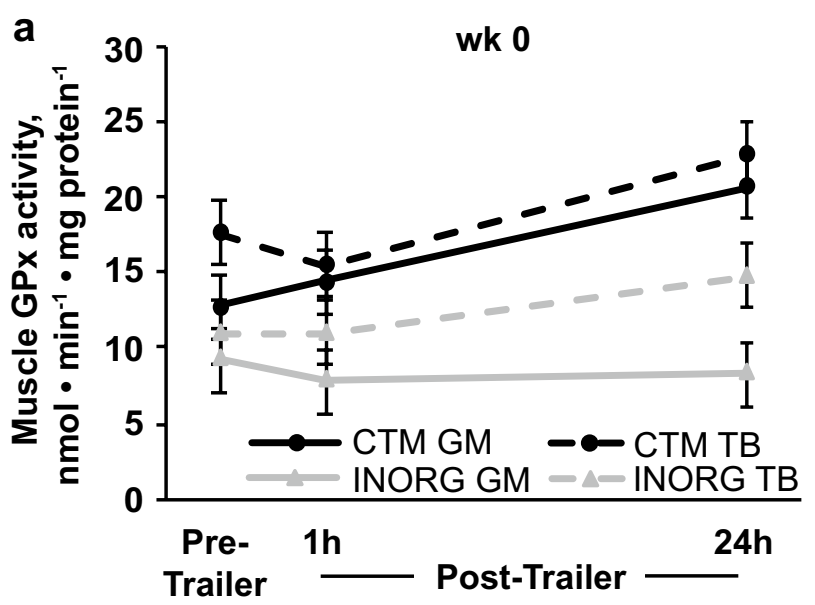

b

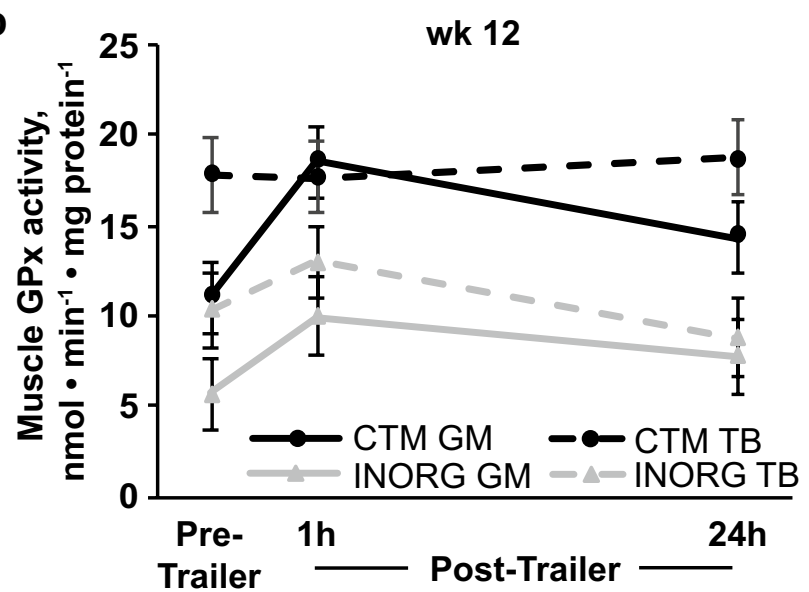

$\mathbf{C}$

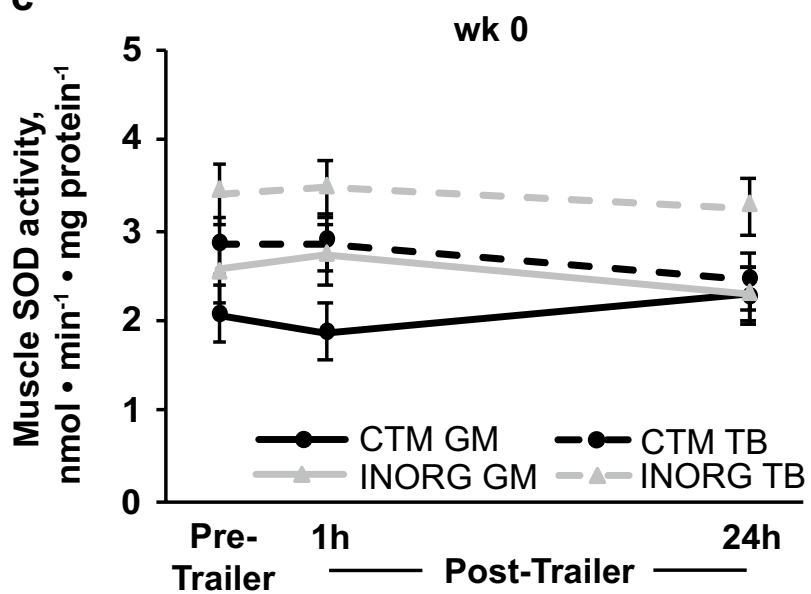

d

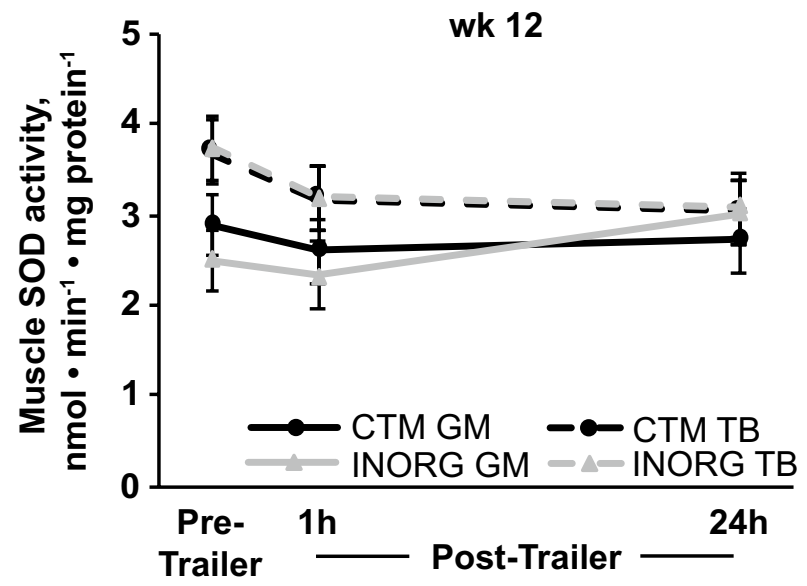

Figure 3. Gluteus medius (GM) and triceps brachii (TB) glutathione peroxidase (GPx; a,b) and superoxide dismutase (SOD; c,d) activites before (pre-trailer), and $1(1 \mathrm{~h})$ and $24 \mathrm{~h}(24 \mathrm{~h})$ after a 1.5-h trailer stressor. Trailer stressors occurred before (week 0 ; a,c) and after (week 12; b,d) 12 weeks of submaximal exercise training in yearling horses supplemented with either complexed trace minerals $(C T M ; n=8)$ or inorganic trace minerals (INORG; $\mathrm{n}=8)$. Overall effect of diet $(P=0.0002 ; P=0.0003 ; P=0.061 ; P=0.941)$, trailering $(P=0.055 ; P=0.011$; $P=0.697 ; P=0.662)$, muscle group $(P=0.005 ; P=0.001 ; P<0.0001 ; P=0.011)$, diet $\times$ trailering $(P=0.370$; $P=0.522 ; P=0.737 ; P=0.777)$, diet $\times$ muscle group $(P=0.307 ; P=0.979 ; P=0.507 ; P=0.367)$, time $\times$ muscle group $(P=0.941 ; P=0.069 ; P=0.701 ; P=0.501)$ and $\operatorname{diet} \times$ time $\times$ muscle group $(P=0.533 ; P=0.485 ; P=0.415$; $P=0.443)$ for panels $(\mathbf{a}-\mathbf{d})$, respectively.

from those of growth. More research is needed to determine the individual impacts of growth and training on skeletal muscle redox response to trailer stress in young horses. Additionally, the isolated effects of repeated muscle micro-tissue collections on serum CK in horses should be defined.

Muscle SOD activity was similar amongst all horses through 12 weeks of dietary treatments, prior to enrollment in an exercise training program (prior study; Supplemental Table S2). However, following 12 weeks of exercise and growth (current study), muscle SOD activity increased in both muscle groups of CTM horses, but not INORG horses. Improvements to the energy-producing cells of skeletal muscle, mitochondria, following submaximal exercise training has been demonstrated in 2-year-old Quarter Horses by an increase in intrinsic mitochondrial capacities of complex I and complex II of the electron transport system following 9 weeks of submaximal exercise training ${ }^{12}$. While the efficiency of mitochondrial coupling also increased ${ }^{12}$, which would decrease the loss of electrons during ATP production, mitochondria remain a source of potentially damaging byproducts of energy production, reactive oxygen species, during exercise ${ }^{13}$. Therefore, antioxidant status becomes particularly important during an exercise training program. As such, a lack of increase in SOD activity exhibited by INORG horses coupled with consistently lower GPx activity may have negative implications for young performance horses. This should be further investigated utilizing a more strenuous exercise regime or acute stressor.

In the current study, SOD activity throughout the week 0 trailer stressor tended to be higher for INORG than CTM horses, whereas GPx activity was higher for CTM than INORG horses in both muscle groups at all sampling times. These results are in contrast to previously published literature in food animals showing an increase in SOD activity in various organs following complexed trace mineral supplementation ${ }^{4,5}$. A similar inverse relationship between SOD and GPx expression and activity has been shown in horses supplemented with dietary antioxidants ${ }^{14,15}$, which has been suggested to indicate a preference for use of the GPx over the SOD 

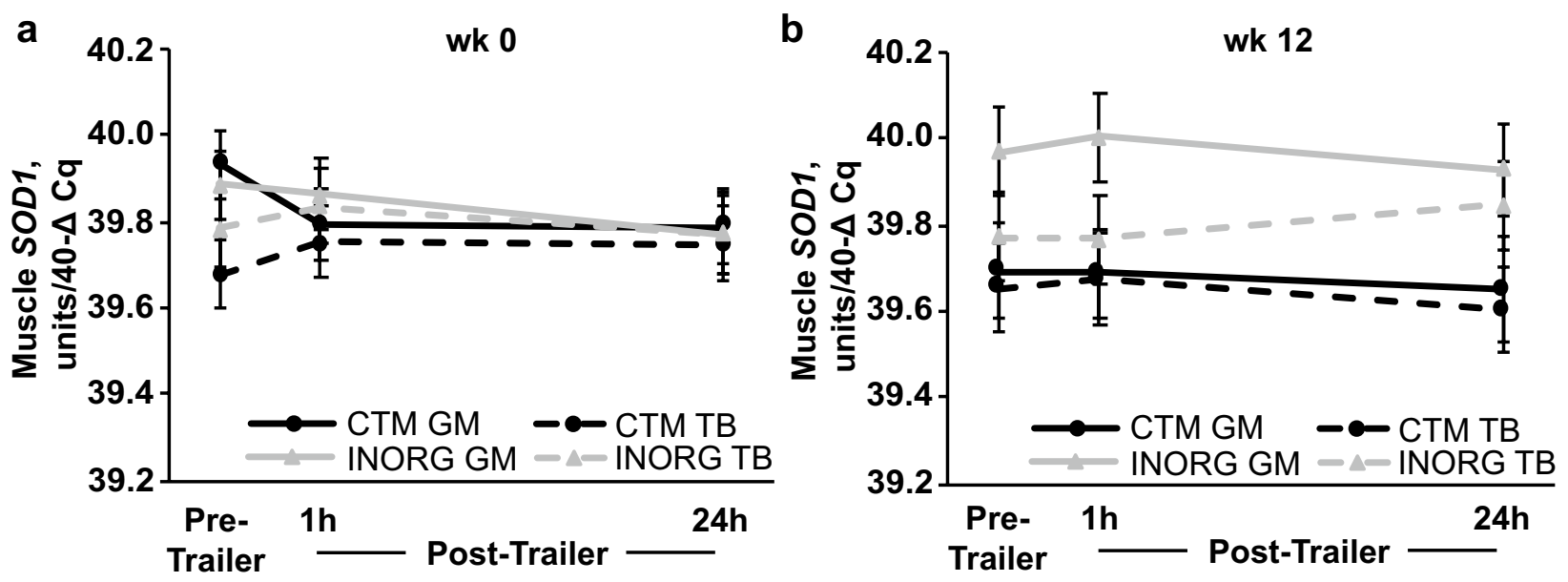

C

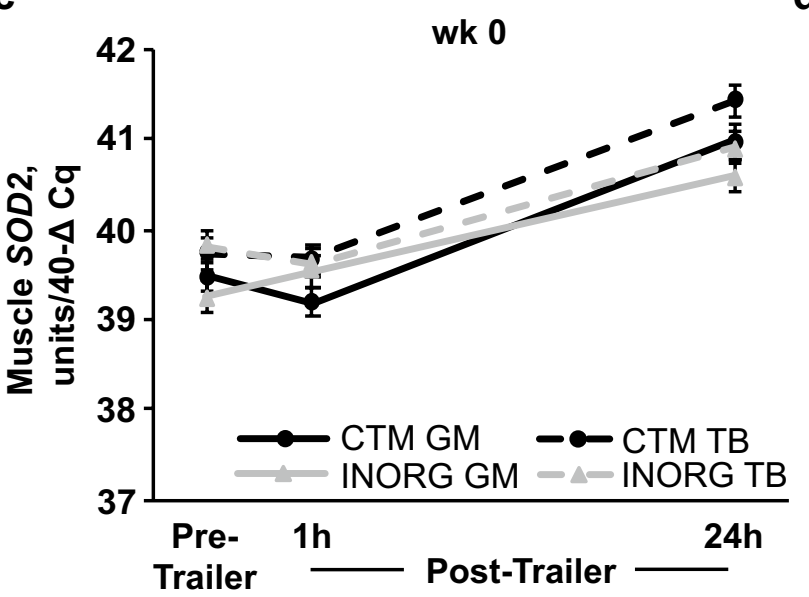

d

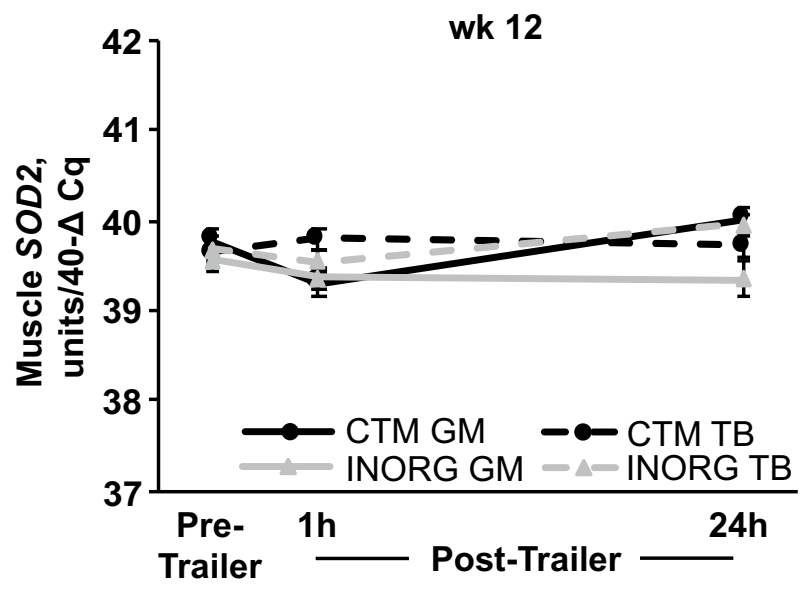

Figure 4. Gluteus medius (GM) and triceps brachii (TB) $\mathrm{Cu}-\mathrm{Zn}$ superoxide dismutase ( $\mathrm{SOD} 1 ; \mathbf{a}, \mathbf{b})$ and $\mathrm{Mn}$ superoxide dismutase (SOD2; c,d) expression before (pre-trailer), and $1(1 \mathrm{~h})$ and $24 \mathrm{~h}(24 \mathrm{~h})$ after a 1.5-h trailer stressor. Trailer stressors occurred before (week $0 ; \mathbf{a}, \mathbf{c}$ ) and after (week 12; b,d) 12 weeks of submaximal exercise training in yearling horses supplemented with either complexed trace minerals $(\mathrm{CTM} ; \mathrm{n}=8)$ or inorganic trace minerals (INORG; $\mathrm{n}=8)$. Overall effect of $\operatorname{diet}(P=0.468 ; P=0.031 ; P=0.907 ; P=0.221$ ), trailering $(P=0.607 ; P=0.922 ; P<0.0001 ; P=0.016)$, muscle group $(P=0.138 ; P=0.050 ; P=0.003 ; P=0.029)$, diet $\times$ trailering $(P=0.932 ; P=0.864 ; P=0.569 ; P=0.717)$, diet $\times$ muscle group $(P=0.403 ; P=0.189 ; P=0.784$; $P=0.052)$, trailering $\times$ muscle group $(P=0.505 ; P=0.881 ; P=0.371 ; P=0.113)$ and diet $\times$ trailering $\times$ muscle group $(P=0.598 ; P=0.782 ; P=0.233 ; P=0.006)$ for panels $(\mathbf{a}-\mathbf{d})$, respectively.

antioxidant system in horses with more favorable antioxidant or selenium (Se) status. The link between CTM supplementation and increased GPx activity in the present study is not clear, as GPx is a selenoenzyme, and Se was not one of the complexed trace minerals supplemented. However, research has shown an increase in GPx activity in the serum and liver of rats following $\mathrm{Zn}$ supplementation ${ }^{16}$. The increased GPx activity purportedly resulted from increased Se availability in tissues in response to $\mathrm{Zn}$ supplementation. Additionally, Cu deficiency has been shown to reduce GPx activity in rats despite maintenance of normal dietary and tissue Se levels, suggesting a Se-independent influence of $\mathrm{Cu}$ on GPx activity ${ }^{17}$. Therefore, bioavailability of dietary trace minerals in the CTM horses may have influenced GPx activity in a Se-dependent or independent manner. More research is needed to determine the effects of individual complexed trace minerals on GPx activity.

At each week, muscle GPx activity increased following the trailer stressor. At week 12, muscle GPx was elevated sooner and returned to pre-trailer values by $24 \mathrm{~h}$ after trailering, further supporting the idea that 12 weeks of exercise training improved the response to a $1.5 \mathrm{~h}$ trailer stressor in yearlings. It is interesting to note that although CTM horses had significantly higher resting GPx activity compared to INORG horses, CTM horses still exhibited an increase in activity in response to trailering. This may result in part from the fact that GPx can be activated by signals other than increased cellular oxidant concentration. For example, GPx is activated

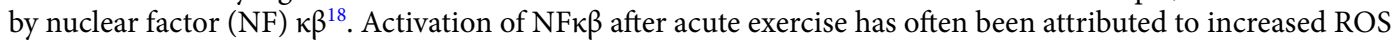
production during exercise, but may also be influenced by pro-inflammatory cytokines and other intermediates independently of exercise-induced ROS $^{19}$. Therefore, it is possible that increases in stress signals independent of ROS caused activation of NFK $\beta$ and therefore an increase in GPx activity in response to trailering.

Following the week 0 trailer stressor, whole blood GPx activity increased $1 \mathrm{~h}$ post-trailering. These results are contrary to studies that have shown either no change $\mathrm{e}^{20}$ or a decrease in systemic GPx activity in horses following 
transportation ${ }^{21}$, but similar to results showing an increase in muscular and systemic GPx activities following an acute exercise bout ${ }^{15}$. Differences between our results and previous studies of transportation stress may have arisen due to differences in length of transportation or the age of horses in the studies. There was no change in blood GPx activity following the week 12 trailer stressor, further suggesting that 12 weeks of exercise training attenuated redox response to the trailer stressor.

Activity of SOD tended to be lower for CTM than INORG horses throughout the trailer stressor at week 0, and was accompanied by a greater SOD2 expression response to trailering for CTM horses. At week 12, growing horses supplemented with dietary complexed trace minerals showed similar SOD activity and expression to INORG horses throughout the trailer stressor. Therefore, 12 weeks of exercise training in growing horses in addition to CTM supplementation ultimately led to similar SOD activities between treatments, but higher sustained GPx activity for CTM horses.

At both sampling intervals, the trailer stressor induced an increase in SOD2 expression at $24 \mathrm{~h}$ post-trailering. Since ROS and inflammatory cytokines are known to regulate transcription of SOD2 $2^{22,23}$, the increase in SOD2 expression at $24 \mathrm{~h}$ post-trailer again suggests that redox balance of the horses may have been affected by the trailer stressor. As such, we would have expected an increase in oxidative stress as indicated by an increase in MDA concentration at week 12. An alternative marker to MDA, such as protein carbonyls or lipid hydroperoxides, or different sampling intervals may have revealed a more prevalent oxidative stress response. Conversely, an increase in inflammatory cytokine signaling following trailering could have also been responsible for the observed increase in SOD2 expression.

The GM is composed of a greater percentage of fast-twitch, non-oxidative fibers when compared to the $\mathrm{TB}^{24}$. Additionally, the TB has been found to have higher indices of mitochondrial density ${ }^{12}$. In the present study, resting MDA concentration, GPx activity, SOD activity, and SOD2 expression were higher in the TB than the GM. These data suggest that in addition to having a lower percentage of fast-twitch, non-oxidative fibers and higher mitochondrial density, the TB also has a higher antioxidant capacity when compared to the GM. Interestingly, SOD1 expression was higher in the GM than the TB. Similarly, the semimembranosus, which contains a low proportion of type I and type IIa muscle fibers, had the highest expression of SOD1 in a study of beef cattle ${ }^{25}$. These data in conjunction with our results suggest that SOD1 expression is higher in less oxidative muscle groups. Therefore, the propulsive and stabilization functions of the GM and TB, respectively, are reflected by differences in fiber type and mitochondrial density, as well as by differences in oxidative by-products and antioxidant activity and expression.

\section{Conclusion}

In the present study of yearling horses, trailering caused an increase in CK activity and muscle MDA concentrations, and changes in antioxidant defense systems indicative of alterations in redox homeostasis. Growing horses showed decreased systemic markers of muscle damage and resting MDA concentrations, increased resting SOD activity and SOD2 expression in the GM, and attenuated responses of MDA, CK and blood GPx activity associated with trailer stress through 12 weeks of submaximal exercise training. Supplementation with complexed trace minerals increased muscle GPx activity at rest and in response to trailer stress, ultimately leading to preferential utilization of the GPx system over the SOD system in response to oxidative stress in young untrained horses. However, after 12 weeks of exercise training, horses supplemented with CTM exhibited increased muscle SOD activity, and maintained significantly higher muscle GPx activity. Therefore, complexed trace minerals may be a useful tool for mitigating oxidative stress to maintain muscle health in young equine athletes.

\section{Methods}

Horses. This study was reviewed and approved by the Texas A\&M Institutional Animal Care and Use Committee (IACUC; 2016-0294). All experiments were performed in accordance with IACUC guidelines and regulations. Sixteen yearling Quarter Horses (7 fillies and 9 colts) with a mean age of 9.7 mo (SD 0.7) and BW of $295 \mathrm{~kg}$ (SEM 5) were used in this study. Horses were housed in paddocks by sex ( 0.53 and 0.72 ha for colts and fillies, respectively) at the Texas A\&M University Freeman Arena Facility in College Station, TX.

Dietary treatments. Horses were grouped by age, sex, and BW and randomly assigned to receive custom concentrates containing either complexed (CTM; Zn-Met, Mn-Met, Cu-Lys, and Co-glucoheptonate; $n=8$ ) or inorganic (INORG; $\mathrm{CuSO}_{4}, \mathrm{ZnSO}_{4}, \mathrm{MnSO}_{4}$ and $\mathrm{CoCO}_{3} ; \mathrm{n}=8$ ) supplemental trace minerals. Horses were enrolled in a separate but related study prior to the beginning of this study ${ }^{26}$. Therefore, all horses had received the experimental treatments for 12 weeks prior to the current experiment. Horses were allocated to separate pens by sex and had ad libitum access to coastal Bermudagrass hay and water. Hay intake per horse per day was estimated by the following formula:

$$
\frac{\text { Total hay offered in the pen per day }(\mathrm{kg}) \text { - total hay refused in the pen per day }(\mathrm{kg})}{\text { Number of horses in the pen }} .
$$

Concentrate was offered at $1.25 \% \mathrm{BW} /$ day (DM basis). Horses received grain meals individually in stalls $(3.7 \times 3.7 \mathrm{~m})$ split equally into two meals fed at 0700 and 1700 . Refusals were monitored and recorded daily to calculate intake of concentrate. Total daily intake of estimated hay intake plus concentrate intake was $2.0 \%$ BW/ day (DM basis). Diets were formulated to maintain a BCS of 5 to 6 according to the Henneke body condition scoring system ${ }^{27}$, and to meet all requirements for growing horses undergoing light exercise $\mathrm{e}^{28}$. Throughout the study, BW of horses was recorded weekly using a livestock scale accurate to $1 \mathrm{~kg}$ and heart girth, body length, hip height, and wither height measurements were collected at week 0 and 12 to assess growth. Heart girth and 


\begin{tabular}{|l|l|l|l|}
\hline Nutrient $^{\mathbf{a}}$ & Bermudagrass Hay & INORG & CTM \\
\hline Digestible energy (Mcal/kg) & 1.97 & 2.72 & 2.78 \\
\hline Crude fat (\%) & 2.3 & 7.7 & 7.6 \\
\hline Crude protein (\%) & 12.5 & 19.3 & 20.0 \\
\hline Neutral detergent fiber (\%) & 66.0 & 40.0 & 36.9 \\
\hline Acid detergent fiber (\%) & 35.5 & 25.9 & 24.5 \\
\hline Calcium (\%) & 0.38 & 0.94 & 1.20 \\
\hline Phosphorus (\%) & 0.26 & 0.92 & 1.05 \\
\hline Selenium $(\mathrm{mg} / \mathrm{kg})$ & 0.39 & 0.73 & 0.97 \\
\hline Zinc $(\mathrm{mg} / \mathrm{kg})$ & 29 & 142 & 210 \\
\hline Manganese $(\mathrm{mg} / \mathrm{kg})$ & 187 & 157 & 212 \\
\hline Copper $(\mathrm{mg} / \mathrm{kg})$ & 8 & 50 & 58 \\
\hline Cobalt $(\mathrm{mg} / \mathrm{kg})$ & 0.00 & 6.14 & 8.04 \\
\hline
\end{tabular}

Table 4. Nutrient composition of bermudagrass hay, inorganic (INORG) concentrate and complexed trace

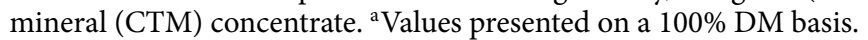

body length were measured using a flexible measuring tape. Hip height and wither height were measured using an altitude stick. Measurements were collected by the same two individuals throughout the study, and averaged at each time point to obtain heart girth, body length, hip height, and wither height values.

All feeds were analyzed prior to beginning the study. Concentrates were analyzed by Equi-Analytical Laboratories (Ithaca, NY), and hay was analyzed by Elk River Forage Lab (Elk River, MN) using standard analytical methods (Table 4). Actual intake of each mineral of interest is presented in Supplemental Table S3.

Exercise. Horses received no forced exercise prior to the beginning of this study. Beginning at week 0, horses were enrolled in a 12-week submaximal exercise program. To facilitate trailer transportation and sample collection, horses were further divided into eight collection groups each with equal representation of dietary treatments. Exercise training, sampling and trailering were initiated in one pair of horses per day over two weeks with four consecutive days of exercise training, trailering and sample collection initiation each week. Exercise was designed to achieve light work as defined by the $\mathrm{NRC}^{28}$, and consisted of $12 \mathrm{~min}$ of walking, 15 min of trotting, and $3 \mathrm{~min}$ of cantering in a free-stall exerciser ( $30 \mathrm{~min}$ total/day) 5 days/week. Each gait was performed daily for an equal amount of time in both directions, and horses alternated starting the exercise bout clockwise or counterclockwise. The speed of each gait was progressively increased throughout the study as horses grew to ensure that all horses remained in the intended gait. Gait speeds started at $1.1 \mathrm{~m} / \mathrm{s}$ for the walk, $2.5 \mathrm{~m} / \mathrm{s}$ at the trot and $5.0 \mathrm{~m} / \mathrm{s}$ at the canter at the beginning of training and were increased to $1.2 \mathrm{~m} / \mathrm{s}$ at the walk, $3.0 \mathrm{~m} / \mathrm{s}$ at the trot and $5.4 \mathrm{~m} / \mathrm{s}$ at the canter by the end of the 12 -week exercise training program.

Trailer stressor. Before beginning exercise training (week 0), and after 12 weeks of exercise training (week 12), horses were trailered for $1.5 \mathrm{~h}$ to assess the effects of trailer stress on antioxidant activity and markers of oxidative stress and muscle damage. Horses were trailered in pairs with equal representation of dietary treatements, tied in the front-most stall of a gooseneck stock trailer. Trailering was performed between 0800 and 1000, on the same route, and by the same driver for all trailering sessions. The average temperatures during trailer sessions were $14.5 \pm 2.2{ }^{\circ} \mathrm{C}$ and $21.2 \pm 2.3^{\circ} \mathrm{C}$ at week 0 and 12 , respectively. The average humidity during trailer sessions were $59.7 \pm 7.0 \%$ and $78.1 \pm 4.3 \%$ at week 0 and 12 , respectively. The trailering route was approximately $113 \mathrm{~km}$ in distance, and consisted of approximately $81 \mathrm{~km}$ of highway with no traffic stops, and $32 \mathrm{~km}$ of driving in the city with light traffic and intermittent stops at traffic lights.

Sample collection. Muscle and blood samples were collected surrounding each 1.5-h trailer stressor at week 0 and 12. Muscle samples were collected before, and at 1 and $24 \mathrm{~h}$ post-trailering for analysis of muscle MDA concentration, GPx and SOD activities, and SOD gene expression. Muscle tissue samples were collected from the GM and TB using a tissue collection procedure as previously described ${ }^{15}$. Briefly, horses were sedated with detomidine hydrochloride prior to beginning tissue collection procedures. The collection areas were clipped, scrubbed with a $7.5 \%$ povidone-iodine solution, and then rinsed with a $70 \%$ ethanol solution. The tissue collection sites were desensitized with $0.5 \mathrm{~mL}$ of $2 \%$ lidocaine and a 14 -gauge needle was used to create the initial puncture through the skin. Tissue was collected using a 14-gauge, 9-cm tissue collection needle inserted to a depth of $3.5 \mathrm{~cm}$. The tissue collection site altered between left and right muscle groups at each sampling interval. Samples obtained from the same side of the horse were obtained approximately $2 \mathrm{~cm}$ from the previous insertion site. At each sampling interval, approximately $75 \mathrm{mg}$ (wet weight) of tissue was placed in $1 \mathrm{~mL}$ of RNALater (Invitrogen, Carlsbad, CA) and stored at $-20^{\circ} \mathrm{C}$ until gene expression analysis was performed. An additional $300 \mathrm{mg}$ (wet weight) of muscle tissue was flash frozen in liquid nitrogen and stored at $-80^{\circ} \mathrm{C}$ until enzymatic activity analyses were performed. Flash frozen muscle was cryopulverized into a fine powder for evaluation for SOD and GPx activities and MDA concentration.

Blood samples were collected prior to sedation before trailering, immediately after, and 1,6 and $24 \mathrm{~h}$ after trailering for analysis of serum CK activity and whole blood GPx and SOD activities. At each sampling interval, 
approximately $15 \mathrm{~mL}$ of blood was collected into evacuated containers, containing either no anticoagulant for harvesting of serum or sodium heparin for harvesting of whole blood. Serum samples remained at $25^{\circ} \mathrm{C}$ and plasma samples were placed on ice for approximately $1 \mathrm{~h}$ prior to processing. Samples were then centrifuged at $3,000 \times g$ for $10 \mathrm{~min}$ at $4{ }^{\circ} \mathrm{C}$, and serum and whole blood were harvested and stored at $-80^{\circ} \mathrm{C}$ until analysis.

Malondialdehyde concentration. Muscle samples were evaluated for MDA concentrations per manufacturer instructions using a commercially available kit (Northwest Life Science Specialties, LLC, Vancouver, WA) as previously described ${ }^{29}$. Previously cryopulverized muscle powder was diluted $1 \mathrm{mg}$ tissue (wet weight) to $10 \mathrm{uL}$ assay buffer provided in the kit and sonicated 3 times for $3 \mathrm{~s}$ each on ice, and then centrifuged at $11,000 \times g$ for $10 \mathrm{~min}$ at $4{ }^{\circ} \mathrm{C}$. Homogenate supernatants were collected and stored at $-80^{\circ} \mathrm{C}$ until analysis. Samples were analyzed in triplicate with an intra-assay CV of $3.6 \%$ and an inter-assay CV of $1.4 \%$. Samples for analysis of MDA concentration were within the standard range of the assay $(0.1$ to $10 \mu \mathrm{M})$. Concentration of MDA was normalized to sample total protein concentration, quantified using a Coomassie Protein Assay kit (Thermo Fisher Scientific).

Enzyme activities. Serum samples were analyzed for CK activity as a marker of muscle damage ${ }^{30}$ using a commercially available kit, following manufacturer instructions (CK Liqui-UV; EKF Diagnostics, Boerne, TX). Samples were analyzed in triplicate with an intra-assay CV of $3.9 \%$ and an inter-assay CV of $9.8 \%$. All samples were within the linear range of the assay ( 1 to $1200 \mathrm{U} / \mathrm{L})$.

Whole blood and muscle samples were analyzed for SOD and GPx activities as measures of antioxidant status using commercially available kits (Cayman Chemical Company, Ann Arbor, MI). Muscle tissue that had been previously cryopulverized and stored at $-80^{\circ} \mathrm{C}$ was diluted $1 \mathrm{mg}$ tissue (wet weight) to $40 \mathrm{uL}$ extraction buffer (1 mM EGTA, $210 \mathrm{mM}$ mannitol, $70 \mathrm{mM}$ sucrose, $\mathrm{pH}$ 7.2), and $1 \mathrm{mg}$ tissue (wet weight) to $80 \mathrm{uL}$ extraction buffer for GPx and SOD analysis, respectively. Diluted samples were sonicated using a sonic dismembrator 3 times for $3 \mathrm{~s}$ each on ice, and then centrifuged at $10,000 \times g$ for $15 \mathrm{~min}$ at $4{ }^{\circ} \mathrm{C}$. Homogenate supernatants were collected and stored at $-80^{\circ} \mathrm{C}$ until analysis. Activity of GPx was evaluated in whole blood diluted 1:34 (v/v), and SOD activity was evaluated in whole blood diluted 1:150 (v/v) with assay buffer provided in the respective kits to ensure sample concentration was within the standard curve of assays. Whole blood and muscle samples were analyzed per manufacturer instructions in triplicate for GPx activity and in duplicate for SOD activity. Intraassay CV was $4.5,3.5,4.8$, and $3.6 \%$ and inter-assay CV was $10.3,12.1,9.3$, and $10.1 \%$ for muscle GPx, muscle SOD, blood GPx, and blood SOD activities, respectively. Samples for analysis of GPx and SOD activities were within the dynamic range of the assays ( 50 to $344 \mathrm{nmol} \bullet \mathrm{min}^{-1} \bullet \mathrm{mL}^{-1}$ for $\mathrm{GPx}, 0.005$ to $0.05 \mathrm{U} / \mathrm{mL}$ for SOD). Muscle homogenate and blood sample total protein was quantified using a Coomassie Protein Assay kit (Thermo Fisher Scientific), and all antioxidant enzyme activities were normalized to sample total protein concentration.

Gene expression. Muscle was examined for mRNA expression of antioxidant enzymes $\mathrm{Cu}-\mathrm{Zn}$ superoxide dismutase (SOD1) and Mn superoxide dismutase (SOD2). Briefly, approximately $75 \mathrm{mg}$ (wet weight) tissue was homogenized in TRIzol (Invitrogen) using a bead homogenizer 4 times for $30 \mathrm{~s}$ intervals. 1-Bromo-3-cholorpropane was used to extract RNA from samples followed by isolation on a spin column according to manufacturer instruction (Purelink RNA Mini-kit; Invitrogen). Samples were treated with RNase-free DNase on the column during RNA extraction to remove any DNA contamination. Spectrophotometry was used to assess RNA concentration and optical density (OD) ratios on a 16-well plate. In all cases, RNA yield was greater than $15 \mathrm{ng} / \mathrm{uL}$ and $\mathrm{OD}_{260 / 280}$ was greater than 1.5. Samples were reverse transcribed using the Superscript II Reverse Transcription kit (Invitrogen). Two hundred ng RNA was reverse transcribed to CDNA for the majority of the samples. However, 29 samples had a low ( $<25 \mathrm{ng} / \mathrm{uL})$ RNA yield; for those samples, $120 \mathrm{ng}$ RNA was reverse transcribed. The cDNA from reverse transcription was amplified with SYBR Green PCR master mix and the appropriate forward and reverse primers (Supplemental Table S4). Thermal cycling parameters included a denaturation step of 95 ${ }^{\circ} \mathrm{C}$ for $5 \mathrm{~min}$ followed by 40 cycles at $15 \mathrm{~s}$ at $95^{\circ} \mathrm{C}$ and $1 \mathrm{~min}$ at $60^{\circ} \mathrm{C}$. Efficiency of PCR for each primer set was determined using a standard curve of pooled $\mathrm{cDNA}^{31}$. A Cycle of Quantification (Cq) value was determined for each sample via PCR. Data for each gene were normalized using the geomean of succinate dehydrogenase A (SDHA), hypoxanthine phosphoribosyltransferase 1 (HPRT1), and beta-2 microglobulin (B2M) as reference genes to account for total cDNA in each sample. The resulting $\Delta \mathrm{Cq}$ was calculated by subtracting $\mathrm{Cq}_{\text {geomean }}$ from $\mathrm{Cq}_{\text {gene of interest }}$. In figures, gene expression is represented as $40-\Delta \mathrm{Cq}$, in which 40 is the total number of cycles ran. Fold changes in gene expression are also reported and are calculated using the formula $2^{-\Delta \Delta \mathrm{Cq}}$, in which $-\Delta \Delta \mathrm{Cq}$ is the $\Delta \mathrm{Cq}_{\text {time of interest }}-\Delta \mathrm{Cq}_{\text {PreT }}$ (before trailer stressor) for each horse $\mathrm{s}^{32}$.

Statistical analyses. Investigators remained blinded to dietary treatments through statistical analysis. Differences in serum CK activity, muscle and blood SOD and GPx activities, muscle SOD1 and SOD2 expression, and muscle MDA concentration were analyzed using the MIXED procedure of SAS 9.4 (SAS Institute, Inc, Cary, NC) with repeated measures. The responses to diet, exercise and growth over time (week 0 and 12 pre-trailer) were analyzed separately from responses to trailering at each week. Additionally, the response to trailering at week 0 was analyzed separately from the response to trailering at week 12 . Data were tested for normality and then log-transformed before analysis if not normally distributed. For pre-trailer responses to diet and exercise, $\operatorname{diet}$ (CTM and INORG), time (week 0 and 12), muscle group (GM and TB), and all interactions were included in the model as fixed effects, and horse within diet was a random effect. Sex and collection group were also included in the model and removed if not significant. For responses to trailering, the model included diet, trailering (pretrailer, 1 and 24 h post-trailer for muscle; pre-trailer, $0,1,6$, and $24 \mathrm{~h}$ post-trailer for blood), muscle group, and all interactions as fixed effects, and horse within diet as a random effect. In cases where either week 0 or pre- 
trailer values were significantly different between treatments, the covariate was tested. If the covariate was not significant, it was removed from the model. All data are expressed as least squared means \pm SEM. Significance was considered at $P \leq 0.05$, and trends were acknowledged at $P \leq 0.10$.

\section{Data availability}

The datasets generated during and/or analyzed during the present study are available from the corresponding author on reasonable request.

Received: 8 January 2021; Accepted: 15 March 2021

Published online: 01 April 2021

\section{References}

1. Echeverry, H. et al. Organic trace mineral supplementation enhances local and systemic innate immune responses and modulates oxidative stress in broiler chickens. Poult. Sci. 95, 518-527. https://doi.org/10.3382/Ps/Pev374 (2016).

2. Jacometo, C. B. et al. Maternal consumption of organic trace minerals alters calf systemic and neutrophil mRNA and microRNA indicators of inflammation and oxidative stress. J. Dairy Sci. 98, 7717-7729 (2015).

3. Wang, G. et al. Effects of replacing inorganic trace minerals with organic trace minerals on the production performance, blood profiles, and antioxidant status of broiler breeders. Poult. Sci. 98, 2888-2895 (2019).

4. She, Y., Huang, Q., Li, D. F. \& Piao, X. S. Effects of proteinate complex zinc on growth performance, hepatic and splenic trace elements concentrations, antioxidative function and immune functions in weaned piglets. Asian-Australas J. Anim. Sci. 30, 1160-1167. https://doi.org/10.5713/Ajas.16.0867 (2017).

5. Liu, B. et al. Effects of replacing of inorganic trace minerals by organically bound trace minerals on growth performance, tissue mineral status, and fecal mineral excretion in commercial grower-finisher pigs. Biol. Trace Elem. Res. 173, 316-324. https://doi. org/10.1007/S12011-016-0658-7 (2016).

6. Wagner, E. L. et al. Copper and zinc balance in exercising horses fed 2 forms of mineral supplements. J. Anim. Sci. 89, 722-728. https://doi.org/10.2527/Jas.2010-2871 (2011).

7. Wagner, E. L. et al. Copper, zinc-superoxide dismutase activity in exercising horses fed two forms of trace mineral supplements. J. Equine Vet. Sci. 30, 31-37. https://doi.org/10.1016/J.Jevs.2009.11.008 (2010).

8. Anderson, M. G. The influence of exercise on serum enzyme levels in the horse. Equine Vet. J. 7, 160-165. https://doi.org/10.1111/J. 2042-3306.1975.Tb03258.X| (1975).

9. Lindholm, A. In Proc. Int. Conf. Equine Exer. Phys. 711-727 (Davis, Calif. : Iceep Publications, 1987).

10. Tateo, A., Padalino, B., Boccaccio, M., Maggiolino, A. \& Centoducati, P. Transport stress in horses: Effects of two different distances. J. Vet. Behav. Clin. Appl. Res. 7, 33-42. https://doi.org/10.1016/J.Jveb.2011.04.007 (2012).

11. Codazza, D., Maffeo, G. \& Redaelu, G. Serum enzyme changes and haemato-chemical levels in thoroughbreds after transport and exercise. J. S. Afr. Vet. Assoc. 45, 331-334 (1974).

12. White, S. H., Warren, L. K., Li, C. \& Wohlgemuth, S. E. Submaximal exercise training improves mitochondrial efficiency in the gluteus medius but not in the triceps brachii of young equine athletes. Sci. Rep. 7, 14389. https://doi.org/10.1038/S41598-01714691-4 (2017).

13. Powers, S. K. \& Jackson, M. J. Exercise-Induced oxidative stress: Cellular mechanisms and impact on muscle force production. Physiol. Rev. 88, 1243-1276 (2008).

14. De Moffarts, B., Kirschvink, N., Art, T., Pincemail, J. \& Lekeux, P. Effect of oral antioxidant supplementation on blood antioxidant status in trained thoroughbred horses. Vet. J. 169, 65-74. https://doi.org/10.1016/J.Tvjl.2003.12.012 (2005).

15. White, S. H., Johnson, S. E., Bobel, J. M. \& Warren, L. K. Dietary selenium and prolonged exercise alter gene expression and activity of antioxidant enzymes in equine skeletal muscle. J. Anim. Sci. 94, 2867-2878. https://doi.org/10.2527/Jas2016-0348 (2016).

16. Galażyn-Sidorczuk, M., Brzóska, M., Rogalska, J., Roszczenko, A. \& Jurczuk, M. Effect of zinc supplementation on glutathione peroxidase activity and selenium concentration in the serum, liver and kidney of rats chronically exposed to cadmium. J. Trace Elem. Med. Biol. 26, 46-52. https://doi.org/10.1016/J.Jtemb.2011.10.002 (2012).

17. Prohaska, J. R., Sunde, R. A. \& Zinn, K. R. Livers from copper-deficient rats have lower glutathione peroxidase activity and mRNA levels but normal liver selenium levels. J. Nutr. Biochem. 3, 429-436. https://doi.org/10.1016/0955-2863(92)90018-E (1992).

18. Zhou, L., Johnson, A. P. \& Rando, T. A. Nfkb and Ap-1 mediate transcriptional responses to oxidative stress in skeletal muscle cells. Free Radic. Biol. Med. 31, 1405-1416. https://doi.org/10.1016/S0891-5849(01)00719-5 (2001).

19. Ji, L., Gomez-Cabrera, M. C., Steinhafel, N. \& Vina, J. Acute exercise activates nuclear factor (Nf)-kappa B signaling pathway in rat skeletal muscle. FASEB J. 18, 1499-1506. https://doi.org/10.1096/Fj.04-1846com (2004).

20. Kruljc, P., Cebulj-Kadunc, N., Frangez, R. \& Svete, A. N. Changes in blood antioxidant, biochemical and haematological parameters in police horses on duty. Slov. Vet. Zb 51, 119-129 (2014).

21. Niedzwiedz, A., Nicpon, J., Zawadzki, M., Sluzewska-Niedzwiedz, M. \& Januszewska, L. The influence of road transport on the activities of glutathione reductase, glutathione peroxidase, and glutathione-S-transferase in equine erythrocytes. Vet. Clin. Pathol. 41, 123-126. https://doi.org/10.1111/J.1939-165x.2011.00396.X (2012).

22. Kim, A., Murphy, M. P. \& Oberley, T. D. Mitochondrial redox state regulates transcription of the nuclear-encoded mitochondrial protein manganese superoxide dismutase: A proposed adaptive response to mitochondrial redox imbalance. Free Radic. Biol. Med. 38, 644-654. https://doi.org/10.1016/J.Freeradbiomed.2004.10.030 (2005).

23. Ji, L. Antioxidant signaling in skeletal muscle: A brief review. Exp. Gerontol. 42, 582-593. https://doi.org/10.1016/J.Exger.2007.03. $002(2007)$

24. Snow, D. H. \& Guy, P. S. Muscle fibre type composition of a number of limb muscles in different types of horse. Res. Vet. Sci. 28, 137-144. https://doi.org/10.1016/S0034-5288(18)32735-8 (1980).

25. Ellies-Oury, M., Lorenzo, H., Denoyelle, C., Saracco, J. \& Picard, B. An original methodology for the selection of biomarkers of tenderness in five different muscles. Foods 8, 206. https://doi.org/10.3390/Foods8060206 (2019).

26. Millican, A. A. et al. Evaluation of dietary trace mineral supplementation in young horses challenged with intra-articular lipopolysaccharide. Transl. Anim. Sci. (2020).

27. Henneke, D. R., Potter, G. D., Kreider, J. L. \& Yeates, B. F. A scoring system for comparing body condition in horses. Equine Vet. J. 15, 371. https://doi.org/10.1111/J.2042-3306.1983.Tb01826.X| (1983).

28. Nrc. Nutrient Requirements Of Horses. 6th Rev. Edn, (Natl. Acad. Press, 2007).

29. White, S. H. \& Warren, L. K. Submaximal exercise training, more than dietary selenium supplementation, improves antioxidant status and ameliorates exercise-induced oxidative damage to skeletal muscle in young equine athletes. J. Anim. Sci. 95, 657-670. https://doi.org/10.2527/Jas2016.1130 (2017).

30. Siciliano, P. D., Lawrence, L. M., Danielsen, K., Powell, D. M. \& Thompson, K. N. Effect of conditioning and exercise type on serum creatine kinase and aspartate aminotransferase activity. Equine Vet. J. 27, 243-247. https://doi.org/10.1111/J.2042-3306.1995.Tb049 29.X| (1995). 
31. Gonzalez, J. M., Dijkhuis, R. D., Johnson, D. D., Carter, J. N. \& Johnson, S. E. Differential response of cull cow muscles to the hypertrophic actions of ractopamine-hydrogen chloride. J. Anim. Sci. 86, 3568-3574. https://doi.org/10.2527/Jas.2008-1049 (2008).

32. Livak, K. J. \& Schmittgen, T. D. Analysis of relative gene expression data using real-time quantitative Pcr and the $2-\Delta \delta \mathrm{\delta ct}$ method. Methods 25, 402-408. https://doi.org/10.1006/Meth.2001.1262 (2001).

\section{Acknowledgements}

The authors would like to thank the student workers from Texas A\&M University and the horses for all their hard work, as well as Dr. Jessica Leatherwood who acted as PI for the project that preceeded the project at hand. Funding was provided by the Zinpro Corporation.

\section{Author contributions}

S.H.W. and C.K.L designed the study. C.M.L., E.C.D. and S.H.W conducted the experiment and collected the samples. C.M.L., E.C.D and R.N.O analyzed the samples and collected the data. C.M.L and S.H.W. analyzed and interpreted the data and prepared the manuscript. All authors approved the final version of the manuscript.

\section{Competing interests}

This research was funded by Zinpro Corporation, and Dr. Larson is an employee of Zinpro. Dr. Latham, Dr. White, Emily Dickson, and Randi Owen declare no real or perceived conflict of interest.

\section{Additional information}

Supplementary Information The online version contains supplementary material available at https://doi.org/ 10.1038/s41598-021-86478-7.

Correspondence and requests for materials should be addressed to S.H.W.-S.

Reprints and permissions information is available at www.nature.com/reprints.

Publisher's note Springer Nature remains neutral with regard to jurisdictional claims in published maps and institutional affiliations.

(c) (i) Open Access This article is licensed under a Creative Commons Attribution 4.0 International License, which permits use, sharing, adaptation, distribution and reproduction in any medium or format, as long as you give appropriate credit to the original author(s) and the source, provide a link to the Creative Commons licence, and indicate if changes were made. The images or other third party material in this article are included in the article's Creative Commons licence, unless indicated otherwise in a credit line to the material. If material is not included in the article's Creative Commons licence and your intended use is not permitted by statutory regulation or exceeds the permitted use, you will need to obtain permission directly from the copyright holder. To view a copy of this licence, visit http://creativecommons.org/licenses/by/4.0/.

(C) The Author(s) 2021 